\title{
WOMEN IN A NIGHTMARISH UTOPIA: THE EFFECT OF TECHNOLOGY IN BRAVE NEW WORLD
}

\author{
Sayyed Rahim Moosavinia, Shahid Chamran University of Ahvaz, \\ moosavinia@scu.ac.ir
}

Anis Hosseini Pour, Shahid Chamran University of Ahvaz,

Original scientific paper

DOI: $10.31902 /$ fll.36.2021.4

\begin{abstract}
In Brave New World, Aldous Huxley shows us a society in which technological advances have changed the entirety of human life on earth. The opening of the novel does not strike the reader as dystopian and certainly neither does the title. But as we go on, we find that free thinking is limited or nonexistent by the manipulation of scientific advances like hypnopedia and genetic conditioning. On one hand, Huxley paints a picture-perfect society that is at the height of civilization with genetic and scientific advances. On the other hand, he shows us the nightmarish utopia by the lack of moral values in the society. Utopia turns into dystopia when we witness the inferior role of women and the humiliation of the intellectual. In addition, the natural process of childbirth is controlled in test tubes. Furthermore, there is no place for religion, literature, and family values. Lastly, Huxley warns the readers about what technology devoid of value could do to human beings. What is more, is the effect of technology on women which is portrayed through the image of utopia turned into dystopia: a society that mandates promiscuity in the name of civic duty in addition to the removal of the female body from childbirth. Dystopian literature is by nature critical; hence, women's inferiority along with the misuse of a gendered approach to technology highlights toxic patriarchy in the society. It shows Huxley's warning about the destructive effect of dystopia on women.
\end{abstract}

Keywords: dystopia; women; patriarchy; science; moral values; literature; family

\section{General Overview}

Plato's Republic and St. Augustine's City of Gods are two early important classic books in the genre of utopian literature. Later books in the genre include Sir Thomas More's Utopia which is probably the most famous in the genre. While the former texts offered a rational and religious version of an ideal world, the latter "describes an ideal world in satiric contrast to the faults of his contemporary culture." Therefore, "[t]he complex 
task of holding up two mirrors-one reflecting contemporary tendencies while the other shows how the world should develop-is so difficult a task that aesthetic success in the genre is rare" and Jonathan Swift's Gulliver's Travels, along with Huxley's Brave New World are among the great examples of dystopian novels (Sion 125). Written in the same year as H.G. Wells' Men Like Gods, Huxley wrote his book in 1932 as a reaction to Wells' optimism in the future of technology and genetic science. Wells' hope in the future of science was destroyed by the misuse of technology in World War II and the nuclear destruction of Hiroshima and Nagasaki (ibid 127). We pass through Victorian optimism to what H.G. Wells calls the confusion of a nightmarish twentieth century. The slaughter of the First World War, displaced the Enlightenment optimism in science and reason by a sense of humanity's incapacity to restrain its newly created destructive powers (Cleays 107). While utopian fiction sometimes gives alternatives of egalitarian societies in an attempt to give women a better position, they are often unrealistic and impractical. The dystopian genre is a depiction of a plausible reality in the world that the author lives in; hence, by nature it is critical. The issue of women in dystopian literature becomes a place of criticism for the writer.

This essay discusses the treatment of women in a society that encourages meaningless relationships. Female characters are oscillating between the double standards of traditional gender roles and new forms of "conventionality" in the Fordian state. In the first section, we shall discuss the contradictions regarding the role of women in the society. Next we unravel how feminism views the place of women in reading Brave New World. In the following section, we shall investigate the matter of the genre of Huxley's book. In doing so we hope to tackle the question of whether we are dealing with a dystopia or a utopia. Moving on, by borrowing the word usotpia from Atwood, we can grasp an understanding of the confusion created in regards to women as well as the genre itself. Finally, by looking at the male heroes as utter failures intended by the author, we see how the contradictions in all three arenas of male and female characters in addition to the genre start to make sense.

\section{Women and Traditional Roles}

The World State in Brave New World is an example of a patriarchal society that shows the effects of values based on distorted traditional gender roles. Such gender roles which consider men as rational, strong, decisive and protective, cast women as the opposite: emotional, irrational, weak and submissive (Tyson 81). "Feminists don't deny 
biological differences between men and women, many feminists celebrate those differences;" (ibid 82) however, in Brave New World, these gender roles are distorted in a way that is harmful for women. Brave New World portrays a society that has eradicated all emotional values and in general everything that by traditional gender roles, is considered feminine. As a result, such adjustments lead to the hopelessness of the main characters. Firestone says "if women are a parasitical class living off, and at the margins of, the male economy, the reverse too is true: (male) culture is parasitical, feeding on the emotional strength of women without reciprocity." (127) Later she mentions that the continued economic dependence of women makes a situation of healthy love impossible and that, "women can't afford the luxury of spontaneous love. It is much too dangerous. The love and approval of men is all-important" (138-39). She believes that men are not emotionally-driven and if they pursue romance, it is because they see it as a luxury. On the other hand, women who are considered emotional and romantic see it as a way of securing their lives (ibid). Brave New World shows that these traditional belief systems about feminine and masculine stereotypes are harmful. And it is shown through the sentimental male characters like Bernard and John who suffer for not conforming to masculine standards. Furthermore, female characters are constantly oscillating between traditional gender roles and new notions of conformity that includes promiscuity. The society that lacks feminine values fails to function properly. At the end of the chapter Firestone concludes that,

We have seen that a woman needs love, first, for its natural enriching function, and second, for social and economic reasons which have nothing to do with love. To deny her need is to put herself in an extra-vulnerable spot socially and economically, as well as to destroy her emotional equilibrium, which, unlike most men's, is basically healthy. (145)

By changing the traditional role of women, the "Controllers" of the Fordian state hoped to free themselves from their traditional responsibilities and at the same time benefit from distorted female gender roles. Considering that values like marriage and commitment are feminine, the "Controllers" have created the patriarchal utopia which misuses technology. As a result, one man's utopia turns into a nation's nightmare and the woman's dystopia. 


\section{Brave New World and Feminism}

De Beauvoir asserts that woman herself recognizes that, "the universe as a whole is masculine; it is men who have shaped it and ruled it and who still today dominate it" (725). That is the case for Brave New World; a masculine society made by men, ruled by men in which women are treated as inferior. The patriarchal society relies on the hierarchy of power in which women are unequal; hence inferior. De Beauvoir then adds that woman herself knows that, "she is inferior and dependent; [. .. .] she has never emerged as a subject in front of other members of the group; [. . .], she grasps herself as passive opposite to these humanfaced gods who set goals and standards." She believes that women have always been required to establish themselves against a "counteruniverse". As a result, there is always a paradox in regards to their situation. "[T]they belong both to the male world and to a sphere in which this world is challenged; enclosed in this sphere, involved in the male world, they cannot peacefully establish themselves anywhere" (ibid).

June Deery in her feminist reading of Brave New World, examines the impact of technology not only on the whole society but also on the female citizen (254). She argues that Huxley has failed to directly address issues regarding women and that he is oblivious to his perspective regarding the inferior role of women. Deery also wisely points out the genre and its relevance regarding gender. A dystopia is for sure a negative picture of reality; however, it is not a simple reversal. She believes that Huxley does not completely condemn the inequality of women and the narrator is an evident example; the point of view is that of a man, for the descriptions of Lenina are highly sexualized. Moreover, values like family and marriage are considered as unimportant in a heavily controlled society like the Fordian state. A patriarchal, manmade society with hopes of freedom that utilizes gendered eugenics, harms women and marks them as castaways. In "Freudianism: The Misguided Feminism", Shulamith Firestone writes:

At the turn of the century, then, in social and political thinking, in literary and artistic culture, there was a tremendous ferment of ideas regarding sexuality, marriage and family, and women's role. Freudianism was only one of the cultural products of this ferment. Both Freudianism and feminism came as reactions to one of the smuggest periods in Western civilization, the Victorian Era, characterized by its family-centredness, and thus its exaggerated sexual oppression and repression. Both movements signified awakening: but Freud was merely a diagnostician for what feminism purports to cure. (Firestone 44) 
Firestone argues that Freud failed to solve any problems with his psychotherapeutic solutions and he definitely failed to address any issues regarding women. She mentions that, "psychoanalytic therapy has been proven ineffective, and Freud's ideas about women's sexuality [. . .] [were] literally proven wrong" (42). Later, in "Down with Childhood" she adds that, "it was woman's reproductive biology that accounted for her original and continued oppression, and not some sudden patriarchal revolution, the origins of which Freud himself was at a loss to explain" (73-74). Although at its core, the Fordian state claims to have a practical alternative solution to human life, it fails to satisfy the needs of its residents, or at least the intellectual ones. In the same chapter, Firestone talks about the ever-presence of a patriarchal nuclear family in every society. She argues that any form of biological family brings about the suppression of women and children (73). Thus, it would seem that with the eradication of pregnancy and the absence of family, people should be satisfied with their position in the Fordian state; however, it is not the case. Huxley makes his point by the failure of what only seems like a ridiculed version of a hero, Bernard, and with the tragic death of John that was followed by his frustration with their "brave new world". Firestone in the third chapter of her book named "Love", writes:

That women live for love and men for work is a truism. Freud was the first to attempt to ground this dichotomy in the individual psyche: the male child, sexually rejected by the first person in his attention, his mother, 'sublimates' his 'libido' - his reservoir of sexual (life) energies - into long-term projects, in the hope of gaining love in a more generalized form; thus he displaces his need for love into a need for recognition. This process does not occur as much in the female: most women never stop seeking direct warmth and approval. (127)

Therefore, if we consider qualities like sentiment and emotion as feminine, and regard logic and reason as masculine, as has been an established belief by western culture, we can say that the Fordian state is a patriarchal society with masculine values. Thus we expect that this highly civilized society would at least benefit a minority, men if not women. What Huxley tries to portray is that when such values like family, monogamy and love that are supposed to benefit women, are eradicated, not only do women suffer but the whole society declines. Simone de Beauvoir (qtd. Firestone) argues that, "The word love has by no means the same sense for sexes, and this is one cause of the serious misunderstanding which divide them" (135). Later, she states that women are generally monogamous, better at loving and more 
interested in relationships (ibid). While the World State is the perfect depiction of a society deprived of all these so-called feminine values, it fails to serve its purpose and it is doomed to failure, for without such values societies cannot function.

\section{Dystopia or Utopia}

Despite being one of the best examples in the genre, many readers and scholars find it difficult to categorize Brave New World as dystopian or utopian. Brave New World, opens with introducing the Conditioning Center in London with the World State's motto that reads: "Community, Identity, Stability". The opening chapter of the novel seems to be promising a perfect society in which everything is in order and everyone is happy; however, human cloning and conditioning prove us otherwise. In "Paradise Transformed: Varieties of Nineteenth-Century Utopias," Keneth M. Roemer defines a literary utopia as a detailed narrative description of an imaginary culture that "invites readers to experience vicariously an alternative reality that critiques theirs by opening intellectual and emotional spaces that encourage readers to perceive the realities and potentialities of their cultures in new ways" (79). If the imaginary culture is better than reality, the work is a utopia; if worse, it is a dystopia (ibid). "Brave New World is a profoundly unsettled text. It appears ambivalent-sometimes even confused or confusing in its attitudes towards power, freedom, and the nature of community" (Greenberg and Waddell 2). The confusion and ambiguities do not stop there; readers are baffled when the civilized is contrasted with the uncivilized as they move from London to "Savage Reservation". Also, the ambiguities exist in Lenina and Linda's battle with World State's conformity and patriarchal traditions. Margaret Atwood (qtd. in Greenberg and Waddell) coined the term ustopia which is a word made by "combining utopia and dystopia - the imagined perfect society and its opposites-because each contains a latent version of the other" (78). The woman's place in a man-made utopia gone wrong can be explained by considering ustopia. Huxley plays with the idea of equality in a utopia, then gives us a look into a patriarchal dystopia that enslaves women.

\section{Women in Utopia}

From the beginning of the story we are faced with ranks; people are ranked in a hierarchical order; Alphas, Betas, Gammas, Deltas and Epsilons. Yet the highest rank a woman can occupy, is a "beta-plus female" (184). In the caste system there are also "Alpha plus intellectuals" (18) who are obviously the better caste to be in, for 
"Gammas are stupid ... Epsilons are even worse. They are too stupid . . ." (29). In addition, there are male characters who are clearly in higher positions than women, like Helmholtz and Bernard. "[T]hat is the secret of happiness and virtue-liking what you've got to do. All conditioning aims at that: making people like their unescapable social destiny" (16). These are the lines that the Director says to the students in the tour. The goal of such a society is to keep everyone in control with the illusion of happiness. Ranks in the civilization of London, signifies the power structure that makes any equality impossible. Those in lower ranks including Deltas, Gammas and Epsilons are conditioned and consequently expected to do the hand work. Consequently, the Alphas and Betas are the future leaders of the society. The Director of Hatcheries explains a process called Bokanovsky's Process in which one egg will produce ninety-six human beings:

One egg, one embryo, one adult-normality. But a bokanovskified egg will bud, will proliferate, will divide. From eight to ninety-six buds, and every bud will grow into a perfectly formed embryo, and every embryo into a full-sized adult. Making ninety-six human beings grow where only one grew before. Progress (5).

Thus, not only are the machines mass produced but so are human beings. This mass production brings about the eradication of individuality and freedom. As readers, we cannot help but notice the lack of a female hero, but at the same time we are deprived of any heroes at all. Anytime we think that Bernard or John has any resemblance to a hero, Huxley takes that all away to emphasize the helplessness of this "brave new world". While everyone else is referred to by their caste, the main characters have names that allude to important figures in history. This emphasizes the critical approach of Huxley in writing his novel. Bernard Marx is a character whose search for identity is doomed to failure. His name is the reminder of the Prussian philosopher Karl Marx "whose classificatory arrangement of human classes according to access to resources may be regarded as the literary implication that his name brings to the text" (Butler 103). Lenina Crowne's name alludes to Vladimir Lenin and her name is a "feminized form of Lenin, leader of the Bolshevik Revolution, an ironic association for she feels strongly, as she is programmed to do, about the social caste system, which is far from equality for all" (ibid 103). Helmholtz-Watson's name is the amalgamation of two names; Herman von Helmholtz, a German Scientist and John B. Watson, a psychologist known for his psychological work on behaviorism (ibid 104). Despite having iconic, personalized names, they are all doomed to failure. So the question is, 
was the inferior state of the female characters intentional? And for what purposes? In Brave New World: Contexts and Legacies the main characters are explained to have served an important function:

The key fact of daily life in Brave New World is its infantile banality, about which Bernard, Helmholtz, John, and Mustapha Mond all have their say. These four males singled out for their critical awareness are set off against the stereotypically unreflecting females Lenina and Linda, and the rest of the supporting cast. The range of characters in Brave New World (there are more characters here than in most utopias) results from Huxley's combination of two narrative models, that of the utopia in which a naïve visitor is shown around by an experienced guide, and the dystopia centring [sic] on the developing awareness of one or more dissident intellectuals, and leading to a one-on-one confrontation with authority. (Greenberg, Waddell 22-23)

The example for the naïve visitor (or rather visitors) from the utopia is the students' tour of the lab of "Hatcheries and Conditioning Center;" John's visit to London is an example of the intellectual facing the hardships of dystopia. Each character simultaneously serves a purpose to the utopian and the dystopian society. The utopian promise of equality is shattered by Bernard and John's discomfort with the conditions that this "brave new world" has caused. Similarly, Lenina and Linda's treatment in such a society makes us question the utopian qualities of this dystopia.

Once again, using the word ustopia can help us understand the polarities in Brave New World. Deery writes that, "it is possible to argue that in some areas, despite its being a dystopia, Brave New World offers women a better deal than the contemporary British society of the 1930 s. There is no housework, no wifely subjugation, no need to balance children and a career," then she adds "if women do not appear to have the vote (which in Britain they had gained only six years earlier), then neither do the men" (260). In contrast, there is also the ugly truth about sexual activity regarding women. What is the purpose of such portrayals by the author?

Despite the encouragement of the woman's promiscuity, we also see her discontent. Lenina is seen as desirable only in a sexual way. "'Lenina Crowne?' said Henry Foster, [. . .] 'Oh, she's a splendid girl. Wonderfully pneumatic. I'm surprised you haven't had her."' (47) On another account the Director says, "charming, charming" while "giving her two or three little pats" (17) and later Lenina admits that, "He patted me on the behind this afternoon". (44) Afterwards, "Fanny was 
triumphant", and she says, "That shows what he stands for. The strictest conventionality." (ibid) The normal and conventional lifestyle for women is to be treated like meat and as Deery says, meat that in our society should be lean not fat (261). Furthermore, double standards exist regarding women's behavior since Fanny says, "I really do think you ought to be careful. It's such horribly bad form to go on and on like this with one man. At forty, or thirty-five, it wouldn't be so bad. But at your age, Lenina! No, it really won't do" (43). In "Docile Bodies, Dangerous Bodies,"Sara K. Day mentions interesting remarks about the portrayal of the woman's body and the existing double standards:

The adolescent woman's body has long been the site of contradictory cultural expectations and demands. Occupying the space between childhood and womanhood, between innocence and experience, between purity and fertility, such a body unsettles the ostensibly clear boundaries that dictate, among other things, gender roles and romantic relationships. In response to the tensions located in and projected onto the adolescent woman's body, Western culture has largely taken to portrayals of young women as simultaneously desirable and dangerous, presenting them as creatures whose sexuality must be controlled by implicit or explicit rules and regulations. (75)

In opposition to the well-conditioned, conformist character of Fanny is Lenina who detests promiscuity by showing monogamous tendencies, something that should be avoided at all costs. Fanny says, "it's not as though there were anything painful or disagreeable about having one or two men besides Henry. And seeing that you ought to be a little more promiscuous" (45). Preceding that, Lenina shakes her head and says, "I hadn't been feeling very keen on promiscuity lately. There are times when one doesn't. Haven't you found that too, Fanny?" Fanny nods her head in "sympathy and understanding" and she replies, "one's got to make the effort" (46). The struggle between their own desire and conforming to society is clear when Fanny states that, "one's got to play the game. After all, every one belongs to every one else" (ibid). In this situation, Fanny and Lenina are foil characters and by contrasting these images, Huxley diverts our attention to the treatment of women in such societies. The contradictory expectations from a woman's body along with their discomfort is in accordance with the duality of the genre, and a tool to criticize values of the Western culture.

In Brave New World, there is no place for women in leadership and the only intellectual men are either emasculated like Bernard, or have a tragic death like John. The privilege of learning about the lab and the 
opportunity of receiving knowledge is only given to boys. In "Of Scrivens and sparks," Rachel Dean-Ruzicka talks about the preconceived notion that girls are not good at STEM fields (51); it is only for men and boys. As we see in the Fordian state, science is being handed to boys by men. "Meanwhile, it was a privilege. Straight from the horse's mouth into the notebook. The boys scribbled like mad" (3). Girls and women do not have any learning opportunities. The position of women is significantly lower than men and one cannot help but notice such discriminations. The reason for such portrayals can be put into perspective only when we once again consider the term ustopia. Women are especially lower in status, for in a novel that criticizes the social norms by the medium of the dystopian genre, they cannot be imagined to have a place equal or higher than men. When the civilized is put up against the uncivilized, it is a point of revelation for both the audience and characters, especially Linda and Lenina. When we realize that both worlds are no different when it comes to treating women, it becomes clear that we are dealing with a dystopia. The gendered approach to genetic improvement puts women at a high risk. As a result, women, who are naturally marginalized, undergo harsher circumstances.

\section{Hero-like Men}

Although the common behavior is to objectify the woman and view her as meat, as readers, we also encounter Bernard's disapproval. One of the main behaviors advocated in the Fordian state is sexual activity as a civic duty. Promiscuity which is taught by conditioning from a young age through the means of sexual games, formerly was objected to by Lenina. Following that, it is pointed out by one of the other main characters, Bernard: "Talking about her as though she were a bit of meat.' Bernard ground his teeth. 'Have her here, have her there' [. . .] He would have liked to go up to them and hit them in the face-hard, again and again" (48-9). From the beginning, Bernard Marx is seen as an outcast; he is different from the men in his caste. "He stood eight centimeters short of the standard Alpha height and was slender in proportion. Contact with members of the lower castes always reminded him painfully of this physical inadequacy" (66). In addition, "They say somebody made a mistake when he was still in the bottle-thought he was a Gamma and put alcohol into his blood-surrogate. That's why he's so stunted" (49). All these emphasize how he does not conform to the norms of the society. Bernard is an intellectual whose thoughts challenge the system, making the reader see the fault in it; however, he is ridiculed and emasculated for not resembling the qualities of his caste. It is also mentioned how shy he is, or how he spends time alone, which 
is considered as horrifying. All his qualities are against the traditional gender roles of masculinity. His objections challenge the ideologies of viewing women as "meat"; however, he is also an unfit member of the Alpha plus community. Therefore, while the norm is to have a degrading look towards women, even those who do not conquer such values and behaviors, are too feeble to do anything about it. In Millett's explanation of patriarchy, she asserts that patriarchy is "two fold; male shall dominate female, elder male shall dominate younger" (25).

The Fordian state is the result of a patriarchal, egotistical man's wish of becoming a god-like creator. Reproduction is controlled by the removal of the woman's role. Here, the traditional gender role of a woman is distorted to benefit men's patriarchal system. Introducing the idea of test-tubes, Huxley portrays a society in which childbirth is not a natural process anymore. The Director explains that, "the parents were the father and the mother," later continuing that, "These are unpleasant facts; I know it. But then most historical facts are unpleasant" (25). The role of a mother is lowered to disgust and disapproval in the following lines: "Maniacally, the mother brooded over her children (her children) [. . .] brooded over them like a cat over its kittens; but a cat that could talk, a cat that could say, 'My baby, my baby,' over and over again, [. . .] That smutty word again" (37-9). This refusal of the natural process of reproduction is emphasized in the story of John's mother, Linda. She tells Bernard and Lenina the story of how she got pregnant when she was on the "Savage Reservation" with the Director. Afterwards, she was abandoned by the Director after finding out about her pregnancy. In like manner, she has an abusive relationship with Popé in the "Reservation". Consequently, this raises John's disgust about this relationship. Linda's journey proves the confusion of the female characters. First, she is conditioned to be promiscuous and abandon her traditional gender role as a woman when in the "Civilization", then she is asked to obey them by being submissive and monogamous when in the "Reservation". Once again she is another female figure who is treated inhumanely and unequal to men, and John is the only one who attempts to harm Popé. Although he fails and is ridiculed by him. Both John and Bernard notice the unfair treatment of the women that are dear to them, but they are unable to socially take any action. In addition, they are mentally immobilized.

Evidently, the search for a hero is impossible, for an intellectual like Bernard is no more a viable option. Things change when Bernard Marx meets John the savage in the "Reservation". What we saw from Bernard, gives us hope for a chance in a rebellion or change in the society. After finding out about the Director's secret, Bernard brings John back to the 
"Civilization" with him. Upon revealing the truth about John being the son of the Director, Bernard gains reputation among the Fordian citizens. On the other hand, John shows discomfort living in a society that lacks individuality and freedom. He hates living among the people who do not value religion, family and art. Thus he decides to isolate himself in exile. Little by little, people start to lose interest in Bernard when John refuses to take part in social gatherings with him. So it seems that the only hope of having a hero is lost when it is revealed that Bernard used John for gaining others' approval. Considering the revisions that Huxley made, Donald Watt takes a look at the early worksheet version of Brave New World and compares it with the later, more finished version of it. Watt examines the challenges and complications that Huxley faced while writing his book by comparing the autograph revisions of the book which were added to the typescript. He categorizes these changes into five groups, one of which is the recasting of John's and Bernard's character (369). Watt writes: "Huxley's script suggests that he thought first of making Bernard an orthodox rebel against his society, and then, instead, of making john a potentially redeeming noble savage hero brought into that society from the outside," but the later revisions show that he abandoned both ideas "to create the collapsing structural ironies" (374). "Huxley's initial conception of Bernard's role changed significantly during the course of his revisions" (375). Such changes in the novel and especially the search for a hero seems to have been a challenge for the writer; however, he decided to leave the readers with no heroes to show the World State's hopelessness.

Linda's character emphasizes the clash of World State's ideals with the traditional belief system of the "Reservation". Family values have vanished along with the degrading place of the mother. "The world was full of fathers-was therefore full of misery; full of mothers-therefore of every kind of perversion from sadism to chastity; full of brothers, sisters, uncles, aunts-full of madness and suicide" (41). When she comes back to the "Civilization" by Bernard, Linda is faced with the repulsive reaction of the people about her having a child in a natural way, in contrast to the genetically conditioned production of babies in testtubes. Of course, this is the same reaction she had when she first found out about her pregnancy, for she too once belonged to the "Civilization". For that reason, she has a complicated relationship with her son. Buchanan relates this complication to John's Oedipal complex saying that, "Yet even after he has encountered the many attractive and available women there, John remains obsessed with his mother" (78). One example of their complicated relationship is when Linda is 
crying and John hugs her and she pushes him away, getting angry when he calls her "mother". "I'm not your mother. I won't be your mother," (137) then she starts to slap him multiple times. "'Turned into a savage,' she shouted. 'Having young ones like an animal [. . .] If it hadn't been for you, I might have gone to the Inspector, I might have got away. But not with a baby. That would have been too shameful,'" although when she sees that John is terrified if she were to hit him again, she puts her arms around him and kisses him "again and again" (137-8). Such emotional upheavals show that the confusion has roots that run deep within the characters. Linda, who used to be a well-conditioned member of the "Civilization" and spent twenty years in the "Reservation", cannot function properly in either of the places. She is punished for her promiscuity in New Mexico and humiliated for being a mother in London. She is forever fluctuating between traditional gender roles and Fordian state's new rules of conformity. Such polarities in the portrayal of women emphasize the destructiveness of societies that abuse science in the name of autonomy.

The World State is a society in which people are conditioned to hate values like family, religion, art and literature. The "Controllers" of the Fordian state use soma, sexual games, and feelies as a form of entertainment and as a result, people are occupied with trivial matters. The biological inventions that produce children in bottles is the answer to rid the child of potential Freudian complexes that the family is responsible for (Buchanan 76). Soma has "All the advantages of Christianity and alcohol; none of their defects" (55). Every time the brave new worldians find themselves in emotional situations, they take "delicious soma, half a gramme for a half-holiday, a gramme for a weekend, two grammes for a trip to the gorgeous East," (57)for they are conditioned to do so. From a young age they practice sexual games and when they get older, they attend a kind of cinema known as feely which gives them sensual experiences. All of these are taught and practiced in order to stop people from thinking and protesting. In the same manner, literature is also prohibited because "We haven't any use for old things here," Mond explains. "Particularly when they're beautiful. Beauty's attractive, and we don't want people to be attracted by old things. We want them to like the new ones" (243). "Controllers" of the Fordian state rule over people by keeping them from reading and learning. John argues that, Othello is better than feelies. "Of course it is," Mond agrees, "But that's the price we have to pay for stability. You've got to choose between happiness and what people used to call high art. We've sacrificed the high art. We have the feelies and the scent organ instead" (245). People are also deprived of religion. "'Art, Science-you seem to 
have paid a fairly high price for your happiness,' said the Savage, [. . .] 'Anything else? 'Well, religion, of course,' replied the Controller. 'There used to be something called God-before the Nine Years' War." and when John asks why they are not given books like the Bible, Mond says, "For the same reason as we don't give them Othello: they're old; they're about God hundreds of years ago. Not about God now" (257). James Fisher writes that Huxley's novel is a warning for the inevitability of technological advancements in which he presents his concern in "an ironic voice and with a satiric gaze" (172). Huxley shows that conditioned human beings without emotions do not have control over technology rather, they are controlled by it. Such a technocratic society is programmed to rule out those that do not fit into the system. Those like Lenina, Linda, Bernard and John who show humane values and emotional tendencies are naturally thrown out; Bernard and John for not conforming to traditional gender roles and Linda and Lenina for conforming to them.

\section{Conclusion}

Aldous Huxley satirizes the society's path towards the eradication of values like family, marriage, religion and literature. He warns the readers about the future of the societies that were leaning towards the full control of technology; gendered eugenics. In Brave New World, we see that with the absence of values, everyone is harmed. Most of all women are harmed since they have been marginalized for centuries in addition to a gendered approach towards genetic reform. Brave New World shows the effect of societies ruled by a minority's control over technology on marginalized characters; both women and intellectual men. Women are harmed by the double standard of gender roles set in societies while the men who see the flaws in those treatments cannot do anything about it. The hierarchical nature of such societies does not allow for any protest. Bernard cannot stay a hero anymore and he is sent to exile. John's death is not heroic either, for his death is so abrupt without arousing any sense of sympathy in others. The female characters in the story also have tragic endings. Linda dies in the hospital after overdosing on soma, and Lenina is humiliated after being rejected by John. Therefore, the portrayal of women in Brave New World is a warning for a nightmarish utopia and what it could do to its citizens.

In De Beauvoir's words, women's situation has remained the same throughout history, a condition which is called the woman's character. She is argumentative, cautious and petty, and she does not have the sense either of truth or of accuracy (724). This is why it is important to read Brave New World in this era of vast media consumption. More than 
any time in history, we are consuming media as much as we are producing it. As a result, we are affected by it and at the same time affecting others. More and more women from different cultures and backgrounds are affected by the distorted and narrow ideals of womanhood. Teenagers and young women have been the target of meaningless ideals for many years. They are called either petty and cautious or immoral and vulgar. Hence, awareness of existing double standards can eliminate the sense of inadequacy of what it means to be a woman.

\section{Works Cited}

Buchanan, Brad. "Oedipus in Dystopia: Freud and Lawrence in Aldous Huxley's Brave New World." Journal of Modern Literature 25.3 (2002): 75-89. Print.

Butler, James Odelle. The Power \& Politics of Naming: Literary Onomastics Within Dystopian Fiction. 2010. University of Glasgow, MPHIL Dissertation. Web. 24 June $2020<$ http://theses.gla.ac.uk/1706/ >.

Claeys, Gregory. "The Origins of Dystopia: Wells, Huxley and Orwell." The Cambridge Companion to Utopian Literature. Ed. Claeys, Cambridge UP, 2010. 107-131. Print.

Day, Sara K. "Docile Bodies, Dangerous Bodies: Sexual Awakening and Social Resistance in Young Adult Dystopian Novels." Female Rebellion in Young Adult Dystopian Fiction. Ed. Sara K. Day et al. Ashgate Publishing Limited, 2014. 75-92. Print.

De Beauvoir, Simone. The Second Sex. Knopf, 2010.

Dean-Ruzicka, Rachel. "Of Scrivens and Sparks: Girl Geniuses in Young Adult Dystopian Fiction." Female Rebellion in Young Adult Dystopian Fiction. Ed. Sara K. Day et al. Ashgate Publishing Limited, 2014. 51-74. Print.

Deery, June. "Technology and Gender in Aldous Huxley's Alternative (?) Worlds." Extrapolation. The Kent State UP 33.3 (1992): 258-273. Print.

Firchow, Peter. "Wells and Lawrence in Huxley's 'Brave New World'." Journal of Modern Literature 5.2 (1976): 260-278. Print.

Firestone, Shulamith. The Dialectic of Sex, 2nd ed. New York: A Bantam Books, 1972. Print.

Fisher, James. "'Everyone Belongs to Everyone Else': The Influence of Brave New World on Cinema." Huxley's Brave New World: Essays. Ed. David Garret Izzo and Kim Kirkpatrick. Jefferson: McFarland \& Co., 2008. 172-82. Print.

Greenberg, Jonathan, and Nathan Waddell. Brave New World: Contexts and Legacies. Ed. Greenberg and Waddell. London: Palgrave Macmillan, 2016. Print.

Hamamra, Bilal Tawfiq. "A Foucauldian Reading of Huxley's Brave New World." Theory and Practice in Language Studies 7.1 (2017): 12-17. Print. 
Huxley, Aldous. Brave New World. Web. 3 July 2020 <http://scotswolf.com/aldoushuxley_bravenewworld.pdf $>$.

Millett, Kate. Sexual Politics. Columbia UP, 2016.

Parrinder, Patrick. "Brave New World as a Modern Utopia." Brave New World: Contexts and Legacies. Ed. Jonathan Greenberg and Nathan Waddell. London: Palgrave Macmillan, 2016. 15-30. Print.

Roemer, Kenneth M. "Paradise Transformed: Varieties of Nineteenth-Century Utopias." The Cambridge Companion to Utopian Literature. Ed. Gregory Claeys. Cambridge UP, 2010. 79-106. Print.

Sion, Ronald T. Aldous Huxley and the Search for Meaning: A Study of The Eleven Novels. Jefferson: McFarland, 2010. Print.

Tyson, Lois. Critical Theory Today. 3rd ed. New York: Routledge, 2015. Print.

Watt, Donald. "The Manuscript Revisions of 'Brave New World'." The Journal of English and Germanic Philology 77.3 (1978): 367-382. Print. .

\section{ŽENE U UTOPIJI KOŠMARA: EFEKTI TEHNOLOGIJE U VRLOM NOVOM SVIJETU}

U Vrlom novom svijetu Oldos Haksli nam prikazuje društvo u kojem je tehnološki napredak u cjelosti promijenio ljudski život na zemlji. Početak romana čitaocu se ne čini distopijskim, a svakako ni naslov. Ali kako idemo dalje, otkrivamo da je slobodno razmišljanje ograničeno ili da ne postoji zbog manipulacija naučnim dostignućima kakva su hipnopedija i genetsko uslovljavanje. S jedne strane, Huxley oslikava savršeno društvo koje je na vrhuncu civilizacije uz genetski i naučni napredak. S druge strane, on nam pokazuje košmarnu utopiju zbog nedostatka moralnih vrijednosti u društvu. Utopija se pretvara u distopiju kada posvjedočimo inferiornu ulogu žene i poniženja intelektualca. Osim toga, prirodni proces rađanja kontroliše se epruvetama. Dodatno, nema mjesta za religiju, književnost i porodične vrijednosti. Na kraju, Haksli upozorava čitaoce na to šta tehnologija bez vrijednosti može učiniti ljudskim bićima. Štaviše, učinak tehnologije na žene je prikazan kroz sliku utopije pretvorene u distopiju: društvo koje nalaže promiskuitet $u$ ime građanske dužnosti uz uklanjanje ženskog tijela iz procesa rađanja. Distopijska književnost je po prirodi kritična; dakle, inferiornost žena zajedno sa zloupotrebom rodnog pristupa tehnologiji naglašava toksični patrijarhat u društvu. Tako izgleda Hakslijvo upozorenje o destruktivnom učinku distopije na žene.

Ključne riječi: distopija; žene; patrijarhat; nauka; moralne vrijednosti; književnost; porodica 